\title{
Frugivory of Persea lingue (Lauraceae) and its effect on seed germination in southern Chile
}

\section{Consumidores de frutos de Persea lingue (Lauraceae) en el sur de Chile y su efecto en la germinación de semillas}

\author{
Dafne Gho-Illanes ${ }^{1 *}$, Cecilia Smith-Ramírez ${ }^{1,2}$, Inao A. Vásquez ${ }^{2} \&$ Iván Díaz ${ }^{2}$ \\ ${ }^{1}$ Instituto de Ecología y Biodiversidad (IEB), Las Palmeras 3425, Ñuñoa, Santiago de Chile. \\ ${ }^{2}$ Instituto de Conservación, Biodiversidad y Territorio, Facultad de Ciencias Forestales y Recursos Naturales, Campus Isla \\ Teja, Universidad Austral de Chile, Valdivia, Chile. \\ *dafne.ghoillanes@gmail.com
}

\begin{abstract}
Frugivory is a common interaction mechanism between plants and animals in the temperate rainforest of southern South America. In this study, we examined primary dispersal and predation stages of Persea lingue (Ruiz et Pav.) Nees (Lauraceae), an endemic large-seeded tree of these forests. The main goal was to determine the identity of vertebrate seed dispersers of $P$. lingue, to distinguish legitimate seed dispersers, pulp consumers and seed predators, and their influence on seed germination. In order to know which birds and small mammals were feeding $P$. lingue seeds, we observed 20 $P$. lingue canopies, and live traps baited with $P$. lingue seeds were installed in fragment forests in south-central Chile. To determine whether birds could be legitimate dispersers of $P$. lingue, we collected regurgitated and fecal samples. We examined whether rodents removed the fruit pulp, the seeds, or the whole fruit. Additionally, we studied if seeds placed on the forest floor were removed by rodents. In a final experiment we conducted germination trials to establish whether pulp removal (by birds, rodents, or artificially-removed) influenced germination rates. We found six bird species feeding on P. lingue seeds. None of them defecated intact seeds, but, Turdus falcklandii Quoy \& Gaimard (Turdinae) and Xolmis pyrope (Kittlitz) (Tyrannidae) regurgitated intact seeds. We captured five species of rodents in Sherman traps. Four of them left intact seeds. We did not find any effect of the seed handling types (pulp consumption vs. seed regurgitation) in seed germination rates. However, pulp removal was an important factor for germination success. We conclude that T. falcklandii and $X$. pyrope are legitimate seed dispersers of $P$. lingue, since they swallow the whole fruit and regurgitate the intact seed. Abrothrix olivaceus (Waterhouse) (Cricetidae) and probably Oligoryzomys longicaudatus (Bennett) (Cricetidae) are potential secondary dispersers of $P$. lingue seeds, as they prefer to eat the fruit pulp rather than the seeds.
\end{abstract}

KeYwords: Frugivory, Austral thrush, seed germination, southern temperate rainforest.

\section{RESUMEN}

La dispersión de semillas por endozoocoría es uno de los principales mecanismos de interacción mutualista entre plantas y animales en el bosque templado de Sudamérica. En este estudio indagamos acerca de los mecanismos de dispersión primaria y estadios de depredación de semillas de Persea lingue (Ruiz et Pav.) Nees (Lauraceae), árbol endémico de estos bosques. El objetivo principal fue determinar la identidad de los vertebrados dispersores de semillas de $P$. lingue, distinguiendo dispersores legítimos, de consumidores de pulpa y predadores de semillas, y determinar su efecto en la germinación. Se realizaron observaciones focales de la copa de adultos de $P$. lingue; además, se instalaron trampas Sherman cebadas con frutos de $P$. lingue en fragmentos de bosque en el valle central del centro-sur de Chile. Se colectaron muestras de fecas y semillas regurgitadas, se determinó cuáles especies de roedores consumieron la pulpa, las semillas o los frutos enteros en las trampas. Se examinó si hubo remoción de frutos y semillas desde el suelo. Se realizó un ensayo de germinación para determinar si la forma de la remoción de la pulpa afecta las tasas de germinación. Registramos seis especies de aves consumiendo frutos, ninguna defecó semillas, Turdus falcklandii Quoy \& Gaimard (Turdinae) y Xolmis pyrope (Kittlitz) (Tyrannidae) regurgitaron semillas intactas. Capturamos cinco especies de roedores en las trampas, cuatro dejaron semillas intactas. No encontramos efecto del tipo de manipulación de las semillas en su germinación. La remoción de la pulpa fue determinante para el éxito de germinación. Concluimos que T. falcklandii y X. pyrope son dispersores legítimos de semillas de P. lingue. Abrothrix olivaceus (Waterhouse) (Cricetidae) y probablemente Oligoryzomys longicaudatus (Bennett) (Cricetidae) son potenciales dispersores secundarios, dada su marcada preferencia por la pulpa sobre las semillas.

Palabras claves: Frugivoría, zorzal, germinación, bosque templado lluvioso. 


\section{INTRODUCTION}

Frugivory is an essential process for plant populations, especially when plant regeneration is strongly dependent on seed dissemination by zoochory (Armesto et al. 1996, Jordano 2000, Aizen et al. 2002, Cousens et al. 2008, Moran et al. 2009). Three categories of frugivory are described: (1) legitimate seed dispersers: swallow the whole fruit, defecating or regurgitating the intact seed (endozoochory); (2) pulp consumers: peck fruits to obtain the pulp, dropping the seed; and (3) seed predators: feeds on the seeds, eliminating fruit pulp or swallowing fruits, and digesting the whole content (Jordano \& Schupp 2000, Aizen et al. 2002, Bascompte \& Jordano 2007).

In the temperate forests of southern South America, near $70 \%$ of the tree species show a high prevalence of endozoochorus dispersal syndrome, especially birds and mammals. Along the last 25 years, there has been increasing interest into researching the species involved in endozoochory processes in this forest type (Armesto et al. 1987, Willson et al. 1996, Aizen et al. 2002, Amico \& Aizen 2005, Vergara et al. 2010, Mora \& Soto-Gamboa 2011, Salvande et al. 2011, Orellana et al. 2014). Many of these studies described vertebrates (reptiles, birds and mammals) as dispersers of plant seeds. Other interactions, like secondary dispersal and predation, have scarcely been included in ecological seed studies in southern Chile, and few studies have included the effect of seed consumption by vertebrates in seed germination (Bustamante et al. 1996, Soto-Gamboa \& Bozinovic 2002, Traveset et al. 2006, Reid \& Armesto 2011).

In the southern temperate forests, the morphology of the seed dispersers matches with the size of the seeds (Armesto et al. 1987). Few species have big fruits (more than $9.0 \mathrm{~mm}$ of length sensu Armesto et al. 1987); among them, there is a Lauraceae, Persea lingue (Ruiz et Pav.) Nees. This tree is an endemic tree of this forests been an important component of the forest association which once covered the lowlands in the Chilean central valley. We selected this species to study its interactions with vertebrate animals due to its limited dispersal effectiveness as a consequence of its large sized fruits that can affect its gene movement. Fruits of $P$. lingue ripe between March and May, after growth for 10 to 14 months (Donoso \& Escobar 2006, Vergara et al. 2010), and represent one of the few species of the temperate rainforest with ripe fruits in autumn (Riveros \& Smith-Ramírez 1996, Vergara et al. 2010). The fleshy fruit of this tree is a drupe, which color varies from violet to shiny black, suggesting bird dispersal mechanism (Armesto \& Rozzi 1989, Cousens et al. 2008). In addition, $P$. lingue fruits fallen by gravity can be eaten by understory animals. In some cases, the animals move fruits away from parent plant and consume only the pulp leaving intact seeds. In these cases, biotic vectors, as vertebrates, become postdispersal agents (Vander Wall et al. 2005). Since has been described that $P$. lingue fruit pulp and seed rind exert an inhibitory effect on seed germination, probably animals seed handling may be beneficial to this plant species (Sáenz de Urtury 1986, Donoso et al. 1986, Donoso \& Escobar 2006, Hernández 2007). This could mean that a biotic vector is necessary to stimulate seed germination.

The specific goal was to determine which bird and mammal species feeds on Persea lingue fruits, distinguishing frugivorous quality, and to evaluate the effect of fruit and seed handling behaviors on seed germination rates.

\section{METHODS}

The study site was located in an agricultural and livestock landscape composed by fragment forests and prairies. This landscape is in a central valley of south-central Chile, in Melefquén, Panguipulli, Región de Los Ríos (72 $15^{\circ}-72^{\circ} 45^{\prime}$ $\mathrm{W}$ and $\left.39^{\circ} 40^{\prime}-39^{\circ} 50^{\prime} \mathrm{S}\right)$. The average annual temperature in this region is about $12{ }^{\circ} \mathrm{C}$, with a rainy season from June to September (average annual precipitation 1,800 mm, Vergara et al. 2010). The dominant tree species in the fragments studied were Nothofagus obliqua, Eucryphia cordifolia, Aextoxicon punctatum and Laurelia sempervirens.

During austral autumn, from April 8 to May 20, 2009, we recorded bird feeding on 20 Persea lingue trees, occurring in four forest fragments that sizes approximate to $0.5 \mathrm{ha}$. The trees were located about $250 \mathrm{~m}$ from each other. We placed eight observation stations at the edge of those four fragments, selecting visible canopies with high densities of ripe fruits. In addition, we had three observation stations located under three $P$. lingue canopies, inside three of the four forest fragments studied. One to three observers simultaneously recorded frugivorous birds trough direct observations, using binoculars and a land scope. We used scan samplings during 60 to $120 \mathrm{~min}$ per session, recording species identity, abundance, and residence times in the trees. In each flock, we observed one focal individual randomly chosen, recording feeding behavior and time spent eating during focal period of observation. Behavior consumption categories were: a) swallowing, b) regurgitating, c) pecking and d) crushing. In the 20 canopies, we did a total of $54.4 \mathrm{~h}$ of observation during this 35-day period.

We present the results as: a) visit rate: the average number of visits per hour for each bird species; b) accumulated residence time: the sum of the time of permanence of each individual on the tree, for each species, during the total hours of observations; c) consumption rate: the sum of fruits consumed by focal individuals, divided by the total hours of focal individuals observations for each species.

To record the state of seeds after bird-gut passage, we collected bird feces under the canopy of nine Persea lingue trees. Under each canopy, we installed polyethylene meshes 
of $4 \mathrm{~m}^{2}$ of surface, 1.2 meters above the forest ground. Between April 12 and May 12, we collected feces, fruits and seeds for each mesh every $48 \mathrm{~h}$. Collections were classified as: nude seeds, fresh fruits and dry fruits. When possible the bird species of feces was identified. On 10 occasions we collected seeds and feces immediately after direct observations under focal trees, from previous cleared meshes surfaces. This allowed us to identify the state of the seeds after bird feeding. With data recorded from the meshes, we evaluated the quantity of seeds eaten by potential disperser in relation to the total seed rain, including dispersal by gravity.

To record frugivory of understory birds, such as Rhinocryptidae, and other understory animals, five trials of footprint-traps of 1 x 1 meter were conducted. Traps were established over a flat mud surface covered with sifted flour in four forest fragments. In the center of each trap we placed 20 marked seeds, 20 marked fruits, and five artificial plasticine fruits. Artificial fruits had the same color and smell of $P$. lingue fruits. The smell was obtained by coating artificial fruits with mashed fruit pulp of $P$. lingue. Every $48 \mathrm{~h}$ between April 13 and May 14, we recorded the number of fruits and seeds removed and the types of marks left on the artificial fruits and sifted flour, reapplying fruit pulp smell to artificial fruits.

To record handling behavior of $P$. lingue fruits by rodent, we placed 30 Sherman traps randomly distributed on the forest ground in two fragments. Inside traps we scattered 20 ripe fruits of $P$. lingue. Traps were installed during seven nights (May 8-15 and June 5-7), from 20:00 to 08:00 (20 fruits $\times 30$ traps $\times 7$ nights $=420$ fruit baits). We covered the traps with litter fall to hide them, and placed wool inside to allow mammals survival during the night. Captured individuals were ink-marked to distinguish them from recaptures. In addition, in the same two fragments, in three occasions (June 5-7) we scattered 30 ripe fruits in the forest soil for $16 \mathrm{~h}$ (from nightfall to noon), distributed in two samples separated by 30 meters $(\mathrm{N}=180$ fruit baits). We recorded the number of fruits with pulp removed and missing fruits.

The effect of animal handling on germination of $P$. lingue seeds was evaluated during a 90 day germination trial. We sowed 320 seeds in a Jacobsen chamber. Seeds locations were randomly distributed on the chamber, over humid filter papers, and covered with transparent bells, under stable temperature of $22{ }^{\circ} \mathrm{C}$ (Figueroa 1999), and natural light conditions. The seeds were distributed in four treatments with 80 seeds each one (eight replicates with 10 seeds per treatment): (T1) Seeds regurgitated by birds, obtained from the meshes; (T2) Pulp removed by rodents, obtained from Sherman traps; (T3) Intact fruits, obtained from the meshes; and (T4) Artificially removed pulp (reviewing Samuels \& Levey 2005). All seeds were stored between 7 to 14 days in plastic boxes, and stratified in humid sand during 60 days at environmental temperature, until the germination trial began (modified from Sáenz de Urtury 1986, and Bustamante 1996). After 60 days almost without germination, 30 seeds of each treatment were exposed to solar light during eight hours, waiting to break the seed rind (Donoso \& Escobar 2006). All seeds were returned to the germination chamber on day 61 . The dependency relation among germination and treatments was evaluated with two Chi Square tests, between $\mathrm{T} 1$ and $\mathrm{T} 2$, to $\mathrm{T} 3$ and $\mathrm{T} 4$.

\section{RESULTS}

We recorded 138 flocks of six species visiting Persea lingue canopies. Turdus falcklandii Quoy \& Gaimard (Turdinae) recorded higher visit frequency (65\%), higher number of individuals (65\%), and highest residence time. T. falcklandii, Xolmis pyrope (Kittlitz) (Tyrannidae) and Patagioenas araucana Lesson (Columbidae) swallowed the whole fruit, but only $T$. falcklandii and $X$. pyrope were observed regurgitating intact seeds. T. falcklandii ate nearly double the consumption rate of $X$. pyrope, which is the next important consumer of $P$. lingue fruits (Table I). Enicognathus leptorhynchus (King) (Psittacidae) crushed all fruits and seeds. Curaeus curaeus (Molina) (Icteridae) and Mimus thenca (Molina) (Mimidae) pecked fruit pulp without removing the fruits from the branches (Table II).

Among the 570 feces collected in the meshes, 52\% were from $T$. falcklandii. Its feces is approximately $3 \mathrm{~cm}$ long and $0.5 \mathrm{~cm}$ wide, commonly colored from dark blue to black, with white urea spots in some cases. T. falcklandii feces contained countless fruit pulp remains, small whole seeds and insect fragments. $13.7 \%$ of the feces were from $P$. araucana, which is a characteristic homogeneous and round paste rounding $3.0 \mathrm{~cm}$ of diameter, with colors that range from brown to violet. None of the $P$. araucana feces showed pulp remains, seeds or another recognizable structure. The remaining 33\% of the feces found in meshes were partially damaged or were not recognizable. None of the feces of any species had whole P. lingue seeds.

From fruits and seeds collected in the meshes, 91.9\% fell by gravity $(\mathrm{N}=4986), 4.7 \%$ were seeds regurgitated by birds, clearly recognizable since they didn't have pulp remains on their surface $(\mathrm{N}=254)$, and $3.3 \%$ were fruits pecked by birds, showing its pulp partially removed $(\mathrm{N}=181)$. In ten occasions we collected seeds immediately after direct observations under focal trees, observing high temperature and drops of flesh blood upon the surface of three of the seeds collected.

On the footprint-traps we found ten rodent-type footprints. Rodent teeth marks were found on six of the artificial fruits. There were no records of bird footprints. Rodents removed $52.2 \%$ of the fruits baited in those traps $(\mathrm{N}=94)$. In $79.9 \%$ of the cases rodents removed the whole 
fruits $(\mathrm{N}=75)$, while in $13.8 \%$ the nude marked seeds were removed $(\mathrm{N}=13)$.

We captured 29 individuals of five rodent species; three of them were natives (Table III). We obtained an average of $13.8 \%$ of capture success, with different results depending on the month of captures: in four nights during May, we captured three individuals of three rodent species: Geoxus valdivianus (Philippi) (Cricetidae; $\mathrm{N}=1$ ), Oligoryzomys longicaudatus (Bennett) (Cricetidae; $\mathrm{N}=1$ ), and Rattus norvegicus (Berkenhout) (Muridae; $\mathrm{N}=1$ ). In contrast, in three nights during early June we captured 26 individuals of three species: O. longicaudatus $(\mathrm{N}=18)$, Rattus rattus (Linnaeus) (Muridae; N=5), and Abrothrix olivaceus (Waterhouse) (Cricetidae) $(\mathrm{N}=3)$.

TABLE I. Visit frequencies and residence time for bird species recorded eaten Persea lingue fruits.

TABla I. Frecuencia de visita y tiempo de permanencia de las aves registradas consumiendo frutos de Persea lingue.

\begin{tabular}{|c|c|c|c|c|c|c|}
\hline Species & FAMILY & $\begin{array}{c}\text { NuMBER OF BIRDS } \\
\text { RECORDED }\end{array}$ & $\begin{array}{c}\text { VISITS } \\
\text { RECORDED }\end{array}$ & $\begin{array}{c}\text { VISIT } \\
\text { FREQUENCY }(\%)\end{array}$ & $\begin{array}{c}\text { VISIT RATE } \\
\text { (VISITS/HOUR) }\end{array}$ & $\begin{array}{c}\text { ACCUMULATED RESIDENCE } \\
\text { TIME (HOURS) }\end{array}$ \\
\hline $\begin{array}{l}\text { Turdus falcklandii } \\
\text { "Austral thrush" }\end{array}$ & Turdidae & 232 & 90 & 65.2 & 1.66 & 7.16 \\
\hline $\begin{array}{l}\text { Patagioenas araucana } \\
\text { "Chilean pigeon" }\end{array}$ & Columbidae & 42 & 23 & 16.7 & 0.42 & 2.47 \\
\hline $\begin{array}{l}\text { Curaeus curaeus } \\
\text { "Austral blackbird" }\end{array}$ & Icteridae & 70 & 14 & 10.1 & 0.26 & 1.02 \\
\hline $\begin{array}{l}\text { Xolmis pyrope } \\
\text { "Fired-eyed diucon" }\end{array}$ & Tyrannidae & 12 & 9 & 6.5 & 0.17 & 0.37 \\
\hline $\begin{array}{l}\text { Enicognathus } \\
\text { leptorhynchus } \\
\text { "Slender-billed parakeet" }\end{array}$ & Psittacidae & 1 & 1 & 0.7 & 0.02 & 0.58 \\
\hline $\begin{array}{l}\text { Mimus thenca } \\
\text { "Chilean mockingbird" }\end{array}$ & Mimidae & 1 & 1 & 0.7 & 0.02 & 0.01 \\
\hline
\end{tabular}

TABLE II. Type of fruit handling and fruit consumption rate of bird species eating Persea lingue. Frugivory category: $\mathrm{SD}=$ seed disperser; $\mathrm{PC}=$ pulp consumer; $\mathrm{SP}=$ seed predator.

TABla II. Tasa de consumo y forma de alimentación de aves consumiendo frutos de Persea lingue. Tipo de frugivoría: $\mathrm{SD}=$ dispersor de semillas; $\mathrm{PC}=$ consumidor de pulpa; $\mathrm{SP}=$ depredador de semillas.

\begin{tabular}{|c|c|c|c|c|c|c|c|c|}
\hline Species & FAMILY & 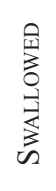 & 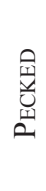 & 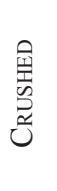 & 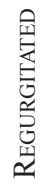 & $\begin{array}{c}\text { AVERAGE } \\
\text { FRUITS } \\
\text { CONSUMED } \\
\text { (FOCAL BIRDS) }\end{array}$ & $\begin{array}{c}\text { CONSUMPTION } \\
\text { RATE PER CAPITA } \\
\text { (FRUITS/HOUR) }\end{array}$ & $\begin{array}{l}\text { FRUGIVORY } \\
\text { (CATEGORY) }\end{array}$ \\
\hline $\begin{array}{l}\text { Turdus falcklandii } \\
\text { "Austral thrush" }\end{array}$ & Turdidae & 57 & 7 & 0 & 9 & 1.016 & 0.125 & SD \\
\hline $\begin{array}{l}\text { Xolmis pyrope } \\
\text { "Fired-eyed diucon" }\end{array}$ & Tyrannidae & 2 & 2 & 0 & 1 & 0.800 & 0.098 & SD \\
\hline $\begin{array}{l}\text { Curaeus curaeus } \\
\text { "Austral blackbird" }\end{array}$ & Icteridae & 0 & 3 & 0 & 0 & 0.333 & 0.041 & $\mathrm{PC}$ \\
\hline $\begin{array}{l}\text { Patagioenas araucana } \\
\text { "Chilean pigeon" }\end{array}$ & Columbidae & 3 & 0 & 0 & 0 & 0.273 & 0.033 & SP \\
\hline $\begin{array}{l}\text { Enicognathus leptorhynchus } \\
\text { "Slender-billed parakeet" }\end{array}$ & Psittacidae & 0 & 0 & 51 & 0 & 51.0 & 6.258 & SP \\
\hline $\begin{array}{l}\text { Mimus thenca } \\
\text { "Chilean mockingbird" }\end{array}$ & Mimidae & 0 & 1 & 0 & 0 & 1.0 & 0.123 & $\mathrm{PC}$ \\
\hline
\end{tabular}


TABLE III. Fruit consumption of Persea lingue in rodents. Range: N= native; I= introduced.

TABLA III. Consumo de frutos de Persea lingue por roedores. Rango: N= nativo; I= introducido.

\begin{tabular}{|c|c|c|c|c|c|c|}
\hline \multirow[t]{2}{*}{ SPECIES } & \multirow[t]{2}{*}{ FAMILY } & \multirow[b]{2}{*}{ RANGE } & \multirow{2}{*}{$\begin{array}{c}\text { CAPTURE } \\
\text { FREQUENCY (\%) }\end{array}$} & \multirow{2}{*}{$\begin{array}{l}\text { CONSUMPTION } \\
\text { FREQUENCY (\%) }\end{array}$} & \multicolumn{2}{|c|}{$\begin{array}{c}\text { CONSUMPTION PREFERENCES } \\
\qquad(\%)\end{array}$} \\
\hline & & & & & Pulp & WHOLE FRUIT \\
\hline $\begin{array}{l}\text { Oligoryzomys longicaudatus } \\
\text { "Long-tailed pygmy rice rat" }\end{array}$ & Sigmodontinae & $\mathrm{N}$ & 65.5 & 58.2 & 68.9 & 31.1 \\
\hline $\begin{array}{l}\text { Rattus rattus } \\
\text { "Black rat" }\end{array}$ & Muridae & I & 17.2 & 25.1 & 31.6 & 68.4 \\
\hline $\begin{array}{l}\text { Abrothrix olivaceus } \\
\text { "Olive-grass mouse" }\end{array}$ & Cricetidae & $\mathrm{N}$ & 10.3 & 13.2 & 80.0 & 20.0 \\
\hline $\begin{array}{l}\text { Geoxus valdivianus } \\
\text { "Long-clawed mole mouse" }\end{array}$ & Cricetidae & $\mathrm{N}$ & 3.5 & 2.6 & 100.0 & 0.0 \\
\hline $\begin{array}{l}\text { Rattus norvegicus } \\
\text { "Brown Norway rat" }\end{array}$ & Muridae & I & 3.5 & 0.9 & 0.0 & 100.0 \\
\hline
\end{tabular}

A total of 227 fruits were consumed in Sherman traps by rodents. $O$. longicaudatus ate 132 P. lingue fruits and seeds; picked the fruit pulp $(\mathrm{N}=91)$, but also the seeds $(\mathrm{N}=38)$, and the whole fruits $(\mathrm{N}=3)$. Abrothrix olivaceus ate 30 whole fruits in the traps; picked only the fruit pulp $(\mathrm{N}=24)$, but also some seeds $(\mathrm{N}=6)$. Rattus rattus ate 57 whole fruits; picked only the fruit pulp $(\mathrm{N}=18)$ and some seeds $(\mathrm{N}=6)$, but mostly the whole fruits $(\mathrm{N}=33)$. Geoxus valdivianus only removed fruit pulp $(\mathrm{N}=6)$, and $R$. norvegicus picked the whole fruits $(\mathrm{N}=2)$. (Table III). From the 30 ripe fruits scattered in the forest soil for $16 \mathrm{~h}$ in June 5 to 7 ( $\mathrm{N}=180$ fruit baits), we recorded 164 fruits with pulp removed, leaving the intact seeds on forest ground $(91.1 \%$; $\mathrm{SE}=0.58)$; and 8 whole fruits removed $(4.4 \% ; \mathrm{SE}=2.08)$.

During the first 59 days of germination trial, we obtained $0.3 \%$ of germination success $(\mathrm{N}=1$, from a sample of 320 seeds). After solar light exposition of the seeds, we found $21.7 \%$ of the seeds germinated $(\mathrm{N}=26$, from a sample of 120 seeds). The germination began seven days after sun exposition. Treatment 3 (whole fruits) did not germinate during the 90 days of the trial, nor after sun light exposition. All the seeds of this treatment showed fungus proliferation. We found no significant difference on germination success between seeds with pulp artificially removed and seeds regurgitated by birds $\left(\mathrm{df}=1, \chi^{2}=2.16, p=0.14\right)$, nor in seeds with pulp totally removed by rodents $\left(\mathrm{df}=1, \chi^{2}=1.31, p=0.14\right)$.

\section{DISCUSSION}

We found that Turdus falcklandii and $X$. pyrope are legitimate dispersers of Persea lingue seeds, since they swallowed the whole fruit and regurgitated intact seeds. We reject that seed dispersal of $P$. lingue seeds occurs by ingestion and subsequent defecation, since in all of the bird feces sampled, intact seeds were absent. This result fits with the gape-width measurements of $T$. falcklandii and $X$. pyrope, which shows that they are capable of feeding on large sized fleshy fruits, but we found that they are unable to swallow them, probably due to restrictions in their digestive tract size capability. The gape-width of $T$. falcklandii and $X$. pyrope is $10 \mathrm{~mm}$ (Armesto et al. 1987), and the minor average width of $P$. lingue fruits in the study area was $10.4 \mathrm{~mm}(\mathrm{~N}=200$ fruits; $\mathrm{SE}=0.052$ ). Blood presence observed on the sharp top of some seeds suggest that ingestion of seeds could be harmful to birds, due to the large size of the seeds in relation with gape-width capability of frugivorous present in study area. Curaeus curaeus was recorded as an occasional and selective pulp consumer. In spite of the high number of $C$. curaeus individuals recorded per visit, they showed scarce affinity for $P$. lingue fruits, probably due to their average width, which is bigger than the gape-width measured for this species (9.7 mm; Armesto et al. 1987) (Table II).

Turdus falcklandii showed the highest relative importance as a potential seed disperser. It was recorded feeding on the fruits each day of observation, reporting more than $50 \%$ of accumulated visits of all species, and the highest fruit consumption rate (Tables I and II). Xolmis pyrope was only occasionally recorded feeding on Persea lingue fruits, probably limited by an aggressive territorial behavior observed in $T$. falcklandii. $P$. araucana was recorded swallowing fruits, but there were no records for this species regurgitating seeds, nor intact seeds in feces were collected. $P$. araucana probably cannot disperse any seeds, since it is a gizzard from the Columbidae family. Thus, we propose $P$. araucana as a seed predator. The results do not agree with 
the role of $P$. araucana as seed disperser, reported in earlier studies (Urban 1934, Bustamante 1992, Donoso \& Escobar 2006). In those studies, the researchers reported the birds foraging on $P$. lingue, but there were no reports about the fate of seeds. Converging with our results, Amico \& Aizen (2005) reported $P$. araucana as a granivorous species.

Enicognathus leptorhynchus was observed in huge flocks of over 50 individuals predating $P$. lingue seeds in the same study area, but there was only one record of one individual eating $P$. lingue fruits and seeds from the treetops sampled. We assess this species as seed predator. We did not find evidence of understory birds as $P$. lingue fruit consumers, such as the Rhinocryptidae family though they were frequently heard in the study area.

Rodent teeth marks on the artificial fruits show they are the main fruit and seed consumer group of the forest floor in the study site. We found rodents removed the pulp of the fruit from the ripe fruits scattered in the forest soil, during early June. Furthermore, rodents preferred the whole fruits to naked seeds in Sherman traps. Both results suggest that rodents are probably secondary dispersers of $P$. lingue seeds.

Data also suggest that gravity is the dominant primary dispersal mechanism for $P$. lingue, due to the higher frequency of seeds fell collected in meshes $(91.9 \%$; $\mathrm{N}=4986$ ), than the intact seeds regurgitated or picked by birds $(8.1 \% ; \mathrm{N}=435)$.

Rodents showed differential affinity for $P$. lingue throughout the season: early in $P$. lingue fruiting season (May) rodents showed no special affinity for $P$. lingue fruits, evidenced in the low capture success $(\mathrm{N}=3)$, but later in season (June) rodents showed more affinity for both fruits and seeds, and capture success enhance $(\mathrm{N}=26)$. From late May to June, the only species fruiting in the fragment studied was $P$. lingue, showing abundant fruit offer over the forest ground in all fragments studied, due to the high abundance of ripe fruits that fell under canopies by gravity. With this evidence, we believe a progressive decrease of food offer in the forest ground while winter is approaching could increase the pressure for rodents to consume seeds.

It has been argued that secondary dispersal could be undervalued, since fruit removal is often recorded as predation, whereas seed movements could be one-step in a multistep seed dispersal process (Vander Wall et al. 2005). Shepherd \& Ditgen (2013) found that four rodent species: A. longipilis (Waterhouse) (Cricetidae), O. longicaudatus, Chelemys macronyx (Thomas) (Cricetidae) and $R$. norvegicus, took Araucaria araucana (Molina) K.Koch (Araucariaceae) seeds in Argentina. The majority of these seeds $(79 \%)$ were deposited in burrows and caches in litter soil. O. longicaudatus was seed predator and $R$. norvegicus deposited the seed in burrow larders with no possibilities of germination, but $A$. longipilis, who removed $43 \%$ of marked seeds, left them in places where the germination was possible. The findings are consistent with these conclusions.
These data suggests that $A$. olivaceus could be an important secondary disperser of $P$. lingue seeds, assessing both the high percentage of fruits dispersed by gravity (91\%), and the marked preference of $A$. olivaceus by the fruit pulp rather than the seeds, even at the end of fruiting season, when the seeds that remained in the forest soil were scarce. With this evidence, we can hypothesize that rodents that remove seed pulps may be a main contribute to dispersal of $P$. lingue seeds.

The native frugivory species that we found feeding on P. lingue: T. falcklandii, P. araucana, X. pyrope, $M$. thenca, $O$. longicaudatus and $A$. olivaceus, are also described as frugivorous species of Cryptocarya alba (Molina) Looser, another Chilean Lauraceae tree (Bustamante et al. 1996). This result are supported by Rezende et al. (2007) study, which found that two phylogenetically linked species tend to interact with the same group of species, showing the role of complementarity and phylogenetic history on interaction patterns.

Germination trial results verify the previously reported inhibitory effect of the pulp (Sáenz de Urtury 1986, Donoso \& Escobar 2006), since whole fruits from Treatment 3 did not germinate and showed fungus proliferation in both pulp and seeds. This evidence supports the positive effect of fruit pulp removal by animal handling.

Germination trial results also indicate to being eaten or handled by animals was not enough to stimulate germination of $P$. lingue seeds. It was necessary to expose the seeds to direct solar light to begin germination. This "sun shock" treatment is commonly given to $P$. lingue seeds in greenhouses to break the seed rind (Bernardo Escobar pers. com.). This result suggests that seed germination depends both on biotic and abiotic factors. Previous studies (Sáenz de Urtury 1986, Donoso \& Escobar 2006) found the same results in laboratory trials with $P$. lingue seeds from other study places.

Earlier studies have found that plant species dispersed by regurgitation have a limited dispersal distance, in contrast with those dispersed by defecation (Cousens et al. 2008). This difference is produced by the higher time of gut pass through the animal's digestive tract, allowing the seed to be released by the animal farther from parent plant (Cousens et al. 2008, Vásquez 2011). In three occasions, we observed and registered 7 to $10 \mathrm{~min}$ between ingestion of the fruit and regurgitation of the seed in T. falcklandii. During this time, individuals were perched in nearby trees and appeared to be waiting for the moment of regurgitation before continuing foraging. This time is higher than mentioned by Wheelwright (1991), who described the behavior of some neotropical birds that regurgitate big seeds, to spent 1-2 min juggling with the seeds in their bills before dropping them. This elongated time of seed retention could be an advantage for $P$. lingue seed dispersal, comparing regurgitation mechanism versus fruit pulp handling in 
branches. Furthermore, in a seed dispersal study in the tree Guettarda viburnoides Cham. et Schltdl. (Rubiaceae), was found that Cyanocorax cyanomelas Vieillot (Corvidae), a fruit pulp consumer, leads to positive population growing of the species, whereas seed dispersal by the legitimate seed disperser by endozoochory, Pteroglossus castanotis Gould (Ramphastidae), has a detrimental effects on the population growth (Loayza \& Knight 2010).

The $P$. lingue seed dispersal distance was documented by Vásquez (2011), in a parallel study conducted in the same study area. He found that $75-90 \%$ of $P$. lingue seeds are dispersed no more than 10 meters away from parental trees. In spite of that, seedlings of $P$. lingue are commonly found more than $20 \mathrm{~m}$ from their parent tree. In comparison, the postdispersal distance of Araucaria araucana seeds moved by $A$. longipilis was $40 \mathrm{~m}$ (Shepherd \& Ditgen 2013). Thus, we believe that probably postdispersal distance would be higher than primary dispersal distance in the case of $P$. lingue, which seeds could be removed by A. olivaceus. Another dispersal agent in the study site could be the wind, with an average speed of $4-5 \mathrm{~km} / \mathrm{h}$ from April to May, with a possible maximum of $70 \mathrm{~km} / \mathrm{h}$ (Webcast website 2014).

We conclude that gravity is the main primary dispersal agent for Persea lingue. Turdus falcklandii is the main primary disperser in bird dispersers assemblage. Abrothrix olivaceus is probably the main secondary disperser for $P$. lingue on a post dispersal stage. The effect of pulp consumers in germination is positive, by pulp removing and consequently of seeds germination inhibition.

\section{ACKNOWLEDGMENTS}

Supported by ICM05-002 \& PFB-23, Institute of Ecology and Biodiversity (IEB). We thank two anonymous reviewers for valuable comments, Alejandro Miranda by his help in the field, owner of forest fragments, Denise Fliegel for english reviewing and Ngenmawida.

\section{REFERENCES}

Aizen, M.A., D. Vázquez \& C. Smith-Ramírez. 2002. Historia natural y conservación de los mutualismos planta-animal del bosque templado de Sudamérica austral. Revista Chilena de Historia Natural 75: 79-97.

Amico, G.G. \& M.A. Aizen. 2005. Dispersión de semillas por aves en un bosque templado de Sudamérica austral: ¿quién dispersa a quién? Ecología Austral 15: 89-100.

Armesto, J.J. \& R. Rozzi. 1989. Seed dispersal syndromes in the rain forests of Chiloé: evidence for the importance of biotic dispersal in a temperate rain forest. Journal of Biogeography 16: 219-226.

Armesto, J.J., C. Smith-Ramírez \& C. Sabag. 1996. The Importance of Plant-Bird Mutualisms in the Temperate Rainforest of
Southern South America. In: R. Lawford, P. Alaback \& F. Fuentes (eds.), High-Latitude Rainforests and Associated Ecosystems of the West Coast of the Americas. Climate, Hydrology and Conservation. pp. 248-265. SpringerVerlag New York Inc., New York, USA.

Armesto, J.J., R. Rozzi, P. Miranda \& C. Sabag. 1987. Plant frugivores interactions in South American temperate forests. Revista Chilena de Historia Natural 60: 321-336.

Bascompte, J. \& P. Jordano. 2007. Plant-Animal Mutualistic Networks: The Architecture of Biodiversity. Annual Review of Ecology, Evolution, and Systematics 38: 56793.

Bustamante, R.O. 1992. Granivoría y esparcimiento entre plántulas y sus plantas madres: el efecto de la distancia entre plantas madres. Tesis Doctoral. Facultad de Ciencias, Universidad de Chile. Santiago de Chile. 104 pp.

Bustamante, R.O. 1996. Depredación de semillas en los bosques templados de Chile. En: J.J. Armesto, C. Villagrán \& M.T.K. Arroyo (eds.), Ecología de los bosques nativos de Chile (eds.), pp. 265-278. Editorial Universitaria, Santiago, Chile.

Bustamante, R.O., A. Walkowiak, C.A. Henríquez \& I. Serey. 1996. Bird frugivory and the fate of seeds of Cryptocarya alba (Lauraceae) in the Chilean matorral. Revista Chilena de Historia Natural 69: 357-363.

Cousens, R., C. Dytham \& R. Law. 2008. Dispersal in Plants. A Population Perspective. Oxford University Press Inc., New York. 232 pp.

Donoso, C. \& B. Escobar. 2006. Persea lingue. En: C. Donoso Zegers (ed.), Las especies arbóreas de los bosques templados de Chile y Argentina, Autoecología. Marisa Cuneo Ediciones, Valdivia, Chile. 678 pp.

Donoso, C., B. Escobar \& M. Cortés. 1986. Germinación de semillas y técnicas de vivero y plantaciones para las especies de los tipos forestales de la Décima Región. Informe de convenio No 102, Proyecto CONAF-UACh. 133 pp.

Figueroa, P. 1999. Germinación de semillas de Cryptocarya alba (Mol.) Looser y Persea lingue Ness bajo distintas condiciones de temperatura. Tesis. Ingeniería Forestal. Facultad de Ciencias Forestales, Universidad de Concepción. Concepción, Chile. 45 pp.

Hernández, R. 2007. Análisis de un cultivo de plantas de Laurelia sempervirens, Persea lingue y Weinmannia trichosperma con dos tipos de fertilización en dos épocas de siembra. Tesis. Ingeniería Forestal. Facultad de Ciencias Forestales, Universidad Austral de Chile. Valdivia, Chile. 68 pp.

Jordano, P. 2000. Fruits and Frugivory. In: M. Fenner (ed.), Seeds: The ecology of regeneration in plant communities, pp. 125-165. CABI Publications, Wallingford, U.K.

Jordano, P. \& E. Schupp. 2000. Seed Disperser Effectiveness: the quantity component and patterns of seed rain for Prunus mahaleb. Ecological Monographs 70(4): 591-615.

LOAYZA, A.P. \& T. KNIGHT. 2010. Seed dispersal by pulp consumers, not "legitimate" seed dispersers, increases Guettarda viburnoides population growth. Ecology 91(9): 26842695.

Mora, J.P. \& M. Soto-Gamboa. 2011. Legítima dispersión de semillas Ugni molinae Turcz (Myrtaceae) por monito del monte, Dromiciops gliroides. Gayana Botánica 68(2): 309312 . 
Moran, C., C. Catterall \& J. Kanowski. 2009. Reduced dispersal of native plant species as a consequence of the reduced abundance of frugivore species in fragmented rainforest. Biological Conservation 142: 541-552.

Murúa, R. 1996. Comunidades de mamíferos del bosque templado de Chile. En: J.J. Armesto, C. Villagrán \& M.T.K. Arroyo (eds.), Ecología de los bosques nativos de Chile, pp. 113133. Editorial Universitaria, Santiago, Chile.

Orellana, J.I., C. Smith-Ramírez, J.R. Rau, S. Sade, A. Gantz \& C.E. VAldivia. 2014. Sincronía fenológica entre el zorzal austral Turdus falcklandii (Turdidae) y sus recursos alimenticios en bosques y praderas del sur de Chile. Revista Chilena de Historia Natural 87: 11.

ReID, S. \& J.J. ARmesto. 2011. Avian gut-passage effects on seed germination of shrubland species in Mediterranean central Chile. Plant Ecology 212: 1-10.

Rezende, E., P. Jordano \& J. Bascompte. 2007. Effects of phenotypic complementarity and phylogeny on the nested structure of mutualistic networks. Oikos 116: 1919-1929.

Riveros, M. \& C. Smith-Ramírez. 1996. Patrones de floración y fructificación en bosques del sur de Chile. En: J.J. Armesto, C. Villagrán \& M.T.K. Arroyo (eds.), Ecología de los bosques nativos de Chile, pp. 235-249. Editorial Universitaria, Santiago, Chile.

SÁenz de Urtury, M.X. 1986. Estudio anatómico y de germinación en lingue (Persea lingue Nees). Tesis. Ingeniería Forestal. Facultad de Ciencias Agrarias y Forestales, Universidad de Chile. Santiago, Chile. 137 pp.

Salvande, M., J.A. Figueroa \& J.J. Armesto. 2011. Quantity component of the effectiveness of seed dispersal by birds in the temperate rainforest of Chiloé, Chile. Bosque (Valdivia) 32(1): 39-45.

Samuels, I.A. \& D.J. LeVEy. 2005. Effects of gut passage on seed germination: do experiments answer the questions they ask? Functional Ecology 19: 365-368.

ShePherd, J.D. \& R.S. Ditgen. 2013. Rodent handling of Araucaria araucana seeds. Austral Ecology 38(1): 23-32.

Soto-GamboA M. \& F. Bozinovic. 2002. Fruit-disperser interaction in a mistletoe-bird system: a comparison of two mechanisms of fruits processing on seed germination. Plant Ecology 159: 171-174.

Traveset, A., A.W. Robertson \& J. Rodríguez-Pérez. 2006. A review on the role of endozoochory in seed germination. In: A.J. Dennis, E.W. Schupp, R.J. Green \& D.W. Westcott (eds.), Seed dispersal: theory and its application in a changing world, pp. 78-101. CAB International, Wallingford, UK.

Urban, O. 1934. Botánica de las plantas endémicas de Chile. Sociedad de Impresores Literarios de Concepción. Concepción, Chile. 289 pp.

Vander Wall, S.B., K.M. Khun \& M. Beck. 2005. Seed removal, seed predation and secondary dispersal. Ecology 86(3): 801-806.

VÁsquez, I. 2011. Patrones espaciales de reclutamiento y dispersión de semillas del árbol Persea lingue (Miers ex Bertero) Ness (Lauraceae) en el bosque del valle del sur de Chile, efectos del hábitat y un corredor. Tesis. Ingeniería en Recursos Naturales. Facultad de Ciencias Agronómicas, Universidad de Chile. Santiago, Chile. 47 pp.

Vergara, P., C. Smith, C. Del Piano, I. Orellana, D. Gho \& I. VÁsQuez. 2010. Frugivory on Persea lingue in temperate Chilean forest: interactions between fruit availability and habitat fragmentation across multiple spatial scales. Oecologia 164: 981-991.

Webcast Website 2014. Panguipulli Metereological Station downloaded on May $2014<$ http://es.windfinder.com/ forecast/panguipulli>

WheElwright, N.T. 1991. How Long do Fruit-Eating Birds Stay in the Plants Where They Feed? Biotropica 23(1): 29-41.

Willson, M.F., C. Smith-Ramírez, C. Sabag \& J.H. Hernández. 1996. Mutualismos entre plantas y animales en bosques templados de Chile. En: J.J. Armesto, C. Villagrán \& M.T.K. Arroyo (eds.), Ecología de los bosques nativos de Chile, pp. 251-264. Editorial Universitaria, Santiago, Chile. 